\title{
Penerapan Analisis SWOT Dalam Menentukan Strategi Pengembangan Bisnis Di Katering Al-Raham Kabupaten Bandung
}

\author{
Salsha Dila Susanti, Woro Priatini, Dias Pratami Putri \\ Universitas Pendidikan Indonesia, Jl. Dr. Setiabudhi No. 229, Bandung 40154, Indonesia \\ *Corresponding Author.E-mail: salshadila3@student.upi.edu (Salsha Dila Susanti)
}

\begin{abstract}
ABSTRAK
Tujuan dari penelitian ini adalah untuk menganalisis apa saja faktor-faktor eksternal dan juga internal dari Katering Al-Raham agar dapat merumuskan strategi pengembangan bisnis yang dapat dilakukan, serta mengevaluasi dan mengembangkan kembali strategi yang paling tepat untuk diterapkan di Katering Al-Raham. Penelitian ini menggunakan metode campuran dengan tipe embedded design Creswell. Data yang diperoleh akan dianalisis menggunakan matriks EFAS (faktor eksternal), matriks IFAS (faktor internal), matriks IE, kuadran SWOT, matriks SWOT, dan QSPM. Hasil penelitian ini adalah strategi yang efektif dilakukan pihak Katering berupa penetrasi pasar serta pengembangan produk. Alternatif strategi yang dapat katering Al-Raham terapkan adalah pemanfaatan teknologi untuk melakukan promosi di media sosial seperti instagram, facebook, tiktok, dsb. Selain itu katering itu jug dapat melakukan refreshment pada produk dengan cara melakukan inovasi menu paket yang ditawarkan.
\end{abstract}

Keywords: Strategi Pengembangan Bisnis; Analisis SWOT; Analisis QSPM; Katering; Kabupaten Bandung

First Received: April 2017

Revised: Mei 2017

Accepted: Juni 2017

Final Proof Received: December 2017

Published: December 2017 


\section{Pendahuluan}

Pariwisata merupakan salah satu industri yang penting bagi setiap negara. Di Indonesia sendiri pariwisata dapat mengalahkan industri migas dan telah menjadi leading sector yang dapat meningkatkan pertumbuhan ekonomi suatu negara. Pariwisata merupakan suatu hal yang konsepsual yang terus berkembang seiring berjalannya waktu menyempurnakan kebutuhan masyarakat saat ini (Ferreira \& Sousa, 2020, hlm 567).

Pariwisata menghasilkan produk pariwisata yang meliputi barang maupun jasa yang dinikmati oleh wisatawan saat melakukan pariwisata (Suprihatin, 2020, hlm 58). Produk pariwisata tersebut dapat berupa akomodasi, angkutan wisata, restoran, dan daya tarik wisata lainnya yang difasilitasi oleh suatu destinasi pariwisata. Keterkaitan pariwisata dengan industri makanan dan minuman menjadikan industri ini harus memiliki pengembangan agar dapat menjadi faktor daya tarik wisatawan. Penyedia makanan dan minuman dalam pariwisata disebut dengan usaha jasa boga salah satunya merupakan katering. Katering sendiri merupakan wirausaha yang melayani pemesanan makanan dan minuman baik untuk pesta maupun untuk penunjang suatu instansi.

Bandung merupakan salah satu kota yang terkenal akan industri makanan dan minumannya. Bahkan saat ini, Kota Bandung telah ditetapkan sebagai destinasi wisata kuliner nasional karena memiliki beragam kuliner yang cukup variatif. Selain itu, di tahun 2018 Kota Bandung telah dinobatkan sebagai Kota Pariwisata Terbaik pada penyelenggaraan Indonesia Attractiveness Award (IAA) 2018. Beberapa penghargaan yang diberikan kepada Kota Bandung, menunjukkan bahwa Kota Bandung memiliki potensi yang besar dalam industri pariwisata. (Primanda, 2018)

Menurut BPS (2019) terdapat 499 pebisnis yang berkecimpung di industri makanan dan minuman di tahun 2017. Pada tahun 2018 pebisnis di industri makanan dan minuman menurun menjadi 269. Namun, pebisnis di Kelurahan Baleendah mengalami kenaikan yang cukup drastis yaitu pada tahun 2017 jumlahnya 139 pebisnis dan di tahun 2018 meningkat menjadi 230 pebisnis. Semakin berkembangnya bisnis katering di Kota Bandung berakibat pada ketatnya persaingan yang dijalani oleh pengusaha di bidang katering ini. Ditambah lagi di tahun 2020 dunia dikejutkan dengan penmuan virus menular yang dikenal dengan Coronavirus (COVID-19) yang berpengaruh terhadap perekonomian dunia. Karena adanya COVID-19 ini industri pariwisata terkena imbasnya. Penerbangan diberhentikan karena mayoritas negara melakukan lockdown begitu pula Indonesia. Hal ini mengakibatkan industri makanan dan minuman serta akomodasi seperti hotel dan juga restoran sepi pengunjung. Salah satu katering yang juga terdampak COVID-19 adalah Katering Al-Raham Kabupaten Bandung.

Katering Al-Raham merupakan salah satu katering yang berada di Kabupaten Bandung sejak tahun 2004. Katering ini terletak di Jl. Raya Laswi No.154, Baleendah, Kab. Bandung. Berdasarkan Peraturan Menteri Kesehatan No. 1096/MENKES/PER/VI/011 Katering Al-Raham ini tergolong ke dalam Jasaboga golongan A2 karena katering ini melayani kebutuhan masyarakat umum dengan pengolahan yang menggunakan dapur rumah tangga dan mempekerjakan tenaga kerja. Adapun data penghasilan Katering Al-Raham 3 tahun terakhir sebagai berikut.

Tabel 1 Data Penghasilan Katering Al-Raham 3 Tahun Terakhir

\begin{tabular}{l|l} 
Tahun & Penghasilan \\
\hline 2018 & 741.125 .500 \\
\hline 2019 & 568.625 .000 \\
\hline 2020 & 161.657 .500
\end{tabular}


Sumber: Data Katering Al-Raham, 2021

Katering Al-Raham ini biasanya melayani katering untuk khitanan, seminar, aqiqah, prasmanan, nasi box, tumpeng, dll. Untuk menu makananya sendiri biasanya di sesuaikan dengan keinginan konsumen. Harga per porsinya berkisar 20-30 ribu per porsi. Perbedaan harga menunya terdapat pada lauk apa yang diinginkan konsumen. Jika menggunakan olahan ayam, harganya berkisar 20-25 ribu. Sedangkan untuk olahan daging sapi harganya berkisar 30 ribu.

\section{Tinjauan Literatur}

\subsection{Definisi Jasa Boga}

Menurut (Gardjito et al., 2016, hlm 1) dalam bukunya menuturkan bahwa "Industri jasa boga merupakan suatu rangkaian kegiatan produktif di bidang peyediaan hidangan, baik hidangan sehari-hari, hidangan insidental dalam berbagai jamuan, serta suguhan pada jamuan-jamuan resmi untuk berbagai macam event dan momen."

\subsection{Penggolongan Jasa Boga}

Menurut MENKES (2011) dalam

Peraturan

No.

1096/MENKES/PER/VI/2011 tentang

Higiene Sanitasi Jasaboga. Jasaboga terbagi ke dalam 3 golongan yaitu golongan A, B, dan $\mathrm{C}$ dimana golongan A terbagi lagi menjadi 3 yaitu A1, A2, dan A3 sebagai berikut:

1. Jasaboga berdasarkan luas jangkauan yang dilayani, dikelompokkan atas :

a. Jasaboga golongan A ;

b. Jasaboga golongan B ; dan

c. Jasaboga golongan C.

2. Jasaboga golongan A merupakan jasaboga yang melayani kebutuhan masyarakat umum, yang terdiri atas golongan A1, golongan A2, dan golongan A3.

a. Jasaboga golongan A1
Jasaboga yang melayani kebutuhan masyarakat umum, dengan pengolahan makanan yang menggunakan dapur rumah tangga dan dikelola oleh keluarga.

b. Jasaboga golongan A2

Jasaboga yang melayani kebutuhan masyarakat umum, dengan pengolahan yang menggunakan dapur rumah tangga dan memperkerjakan tenaga kerja.

c. Jasaboga gologan A3

Jasaboga yang melayani kebutuhan masyarakat umum, dengan pengolahan yang menggunakan dapur khusus dan memperkerjakan tenaga kerja.

3. Jasaboga golongan B merupakan jasaboga yang melayani kebutuhan masyarakat dalam kondisi tertentu, meliputi :

a. Asrama haji, asrama transit, atau asrama lainnya;

b. Industri, pabrik, pengeboran lepas pantai;

c. Angkutan umum dalam negeri selain pesawat udara;

d. Fasilitas pelayanan kesehatan.

4. Jasaboga golongan $\mathrm{C}$ merupakan jasaboga yang melayani kebutuhan masyarakat di dalam alat angkut umum internasional dan pesawat udara.

\subsection{Aspek Kualitas Jasa Boga}

Kualitas merupakan sebuah kondisi yang selalu berubah yang mencakup produk, jasa, manusia dan juga lingkungannya. Terdapat 5 aspek dalam kualitas jasa:

\section{Responsiveness (Daya Tanggap)}

Sebuah kebijakan dalam membantu dan memberikan pelayanan yang cepat dan juga tepat kepada konsumen dengan cara menyampaikan suatu informasi yang jelas. Dalam penyedia jasa boga yang merupakan aspek responsiveness adalah kesigapan para staf dalam menanggapi kebingungan atau pun kesulitan konsumennya.

2. Assurance (Jaminan) 
Kesopanan, pengetahuan dan juga kemampuan para staf agar menumbuhkan rasa percaya dari konsumen terhadap penyedia jasa. Penyedia jasa boga haruslah memiliki staf yang memiliki sopan santun dalam memperlakukan konsumen. Peyedia jasa boga uga memberikan kepastian bahwa konsumen terbebas dari bahaya sehubung dengan apa yang dikonsumsi.

\section{Tangible (Bukti Fisik)}

Kemampuan suatu penyedia jasa dam menunjukan eksistensinya. Aspek ini meliputi perlengkapan, pegawai/staf, dan sarana komunikasi. Dalam hal ini penyedia jasa boga harus memperhatikan kebersihan tempat, kesesuaian penempatan kursi dan yang lainnya, serta penampilan fisik dari pegawainya seperti seragam, kerapian, dan keserasian.

\section{Emphaty (Perhatian)}

Aspek ini lebih bersifat pribadi seperti memberikan perhatian yang bersifat individual kepada konsumen dan sebisa mungkin memenuhi keinginan konsumen. Dalam hal ini penyedia jasa boga haruslah memiliki komunikasi yang baik dengan klien atau konsumennya. Dengan begitu keinginan dari konsumen akan tersampaikan dengan baik tanpa adanya masalah.

\section{Reliability (Keandalan)}

Kemampuan penyedia jasa dalam memberikan pelayanan sesuai dengan yang dijanjikan secara akurat. Sejauh mana penyedia jasa dapat memberikan pelayanan sesuai dengan yang diharapkan oleh konsumen. (Jayanti, 2016, hlm 15-20)

\subsection{Protokol Kesehatan (Pandemi COVID-19) Jasa Boga}

Pandemi COVID-19 mengharuskan setiap masyarakat mematuhi protokol kesehatan untuk mencegah penyebarannya. Berdasarkan keputusan MENKES (2020) protokol kesehatan untuk penyelenggara event atau pertemuan meliputi:

a. Bagi pelaku usaha/penyelenggara event

1) Memperhatikan informasi terkini serta himbauan dan instruksi pemerintah pusat dan pemerintah daerah terkait COVID-19 di wilayahnya. Informasi secara berkala dapat diakses pada laman https://infeksiemerging.kemkes.go .id, www.covid19.go.id, dan kebijakan pemerintah daerah setempat.

2) Memastikan seluruh pekerja/tim yang terlibat memahami tentang pencegahan penularan COVID-19.

3) Memasang media informasi di lokasi-lokasi strategis untuk mengingatkan pengunjung/peserta agar selalu mengikuti ketentuan jaga jarak minimal 1 meter, menjaga kebersihan tangan dan kedisplinan penggunaan masker.

4) Menyediakan fasilitas cuci tangan pakai sabun yang memadai dan mudah diakses oleh pekerja/peserta/pengunjung.

5) Menyediakan handsanitizer di area pertemuan/kegiatan seperti pintu masuk, lobby, meja resepsionis/registrasi, pintu lift dan area publik lainnya.

6) Jika pertemuan dilakukan di dalam ruangan, selalu menjaga kualitas udara di ruangan dengan mengoptimalkan sirkulasi udara dan sinar matahari, serta melakukan pembersihan filter AC.

7) Melakukan pembersihan dan disinfeksi secara berkala (paling sedikit tiga kali sehari) terutama pada pegangan pintu dan tangga, kursi, meja, microphone, tombol lift, pintu toilet dan fasilitas umum lainnya.

8) Larangan masuk bagi pengunjung/peserta/petugas/pekerj a yang memiliki gejala demam, 
batuk, pilek, nyeri tenggorokan, dan/atau sesak nafas.

9) Proses pelaksanaan kegiatan:

a) Pre-event/sebelum pertemuan
(1)Tetapkan batas jumlah tamu/peserta yang dapat menghadiri langsung pertemuan/event sesuai kapasitas venue.
(2)Mengatur tata letak (layout) tempat pertemuan/event (kursi, meja, booth, lorong) untuk memenuhi aturan jarak fisik minimal 1 meter.

(3)Sediakan ruang khusus di luar tempat pertemuan/event sebagai pos kesehatan dengan tim kesehatan.

(4)Menyebarkan informasi melalui surat elektronik/pesan digital kepada pengunjung/peserta mengenai protokol kesehatan yang harus diterapkan saat mengikuti kegiatan seperti mengunakan masker, menjaga jarak minimal 1 meter, cuci tangan pakai sabun dengan air mengalir atau menggunakan handsanitizer dan etika batuk dan bersin.

(5)Reservasi/pendaftaran dan mengisi form self assessment risiko COVID-19 secara online (form 1), jika hasil self assessment terdapat risiko besar maka tidak diperkenankan mengikuti acara pertemuan/kegiatan.

(6)Pembayaran dilakukan secara daring (online).

(7)Untuk peserta/pengunjung dari luar daerah/luar negeri, penerapan cegah tangkal penyakit saat keberangkatan/kedatangan mengikuti ketentuan peraturan yang berlaku.

(8)Memastikan pelaksanaan protokol kesehatan dilakukan oleh semua pihak yang terlibat dalam kegiatan tersebut termasuk pihak ketiga (vendor makanan/vendor sound system dan kelistrikan/vendor lainnya yang terkait langsung).

(9)Menyediakan alat pengecekan suhu di pintu masuk bagi seluruh

pengunjung/peserta/pekerja/pih ak lain yang terlibat.

(10)Mempertimbangkan penggunaan inovasi digital dan teknologi untuk mengintegrasikan pengalaman virtual sebagai bagian dari acara/event.

(11)Menginformasikan kepada peserta untuk membawa peralatan pribadi seperti alat sholat, alat tulis dan lain sebagainya.

(12)Menyiapkan rencana/prosedur kesehatan, mitigasi paparan dan evakuasi darurat yang sesuai dengan pertemuan/event yang direncanakan.

b) Ketibaan tamu/peserta

(1)Memastikan semua yang terlibat dalam kegiatan tersebut dalam kondisi sehat dengan melakukan pengukuran suhu tubuh di pintu masuk. Apabila ditemukan suhu $>37,3$ oC (2 kali pemeriksaan dengan jarak 5 menit), maka tidak diperkenankan masuk ke acara pertemuan/kegiatan.

(2)Memastikan semua yang terlibat tetap menjaga jarak minimal 1 meter dengan berbagai cara, antara lain seperti penerapan prosedur antrian, memberi tanda khusus di lantai, membuat 
jadwal masuk pengunjung dan dibagi-bagi beberapa gelombang atau pengunjung diberi pilihan jam kedatangan dan pilihan pintu masuk, pada saat memesan tiket, dan lain sebagainya.

(3)Menyiapkan petugas di sepanjang antrian untuk mengawasi aturan jaga jarak, pakai masker, sekaligus sebagai pemberi informasi kepada pengunjung/peserta.

c) Saat tamu/peserta berada di tempat pertemuan/event

(1)Jika mengunakan tempat duduk, kursi diatur berjarak 1 meter atau untuk kursi permanen dikosongkan beberapa kursi untuk memenuhi aturan jaga jarak.

(2)Tidak meletakkan item/barang yang ada di meja tamu/peserta dan menyediakan item/barang yang dikemas secara tunggal jika memungkinkan seperti alat tulis, gelas minum dan lain-lain.

(3)Tidak dianjurkan untuk menyelenggarakan event dengan model pengunjung/penonton berdiri (tidak disediakan tempat duduk) seperti kelas festival dikarenakan sulit menerapkan prinsip jaga jarak.

(4)Penerapan jaga jarak dapat dilakukan dengan cara memberikan tanda di lantai minimal 1 meter.

(5)Jika menyediakan makan/minum yang disediakan diolah dan disajikan secara higienis. Bila perlu, anjurkan tamu/peserta untuk membawa botol minum sendiri, disediakan dengan sistem konter/stall dan menyediakan pelayan yang mengambilkan makanan/minuman.

(6)Bila mungkin, pengunjung disarankan membawa alat makan sendiri (sendok, garpu, sumpit).

d) Saat tamu/peserta meninggalkan tempat pertemuan/event

(1)Pengaturan jalur keluar bagi tamu/peserta agar tidak terjadi kerumunan seperti pengunjung yang duduk di paling belakang atau terdekat dengan pintu keluar diatur keluar terlebih dahulu, diatur keluar baris per baris, sampai barisan terdepan dan lain-lain.

(2)Memastikan proses disinfeksi meja dan kursi serta peralatan yang telah digunakan tamu/peserta dilakukan dengan tingkat kebersihan yang lebih tinggi.

(3)Memastikan untuk menggunakan sarung tangan dan masker saat melakukan pekerjaan pembersihan dan saat menangani limbah dan sampah di tempat pertemuan.

(4)Melakukan pemantauan kesehatan tim/panita/penyelenggara.

b. Bagi pekerja

1) Memastikan diri dalam kondisi sehat sebelum keluar rumah, Jika mengalami gejala seperti demam, batuk, pilek, nyeri tenggorokan, dan/atau sesak nafas tetap di rumah dan periksakan diri ke fasilitas pelayanan kesehatan apabila berlanjut, serta laporkan pada pimpinan tempat kerja.

2) Menggunakan masker saat perjalanan dan selama berada di tempat kerja. 
3) Hindari menyentuh wajah, mata, hidung, dan mulut.

4) Memperhatikan jaga jarak minimal 1 meter dengan orang lain.

5) Menggunakan pakaian khusus saat bekerja.

6) Menghindari penggunaan alat pribadi secara bersama seperti alat sholat, alat makan, dan lain-lain.

7) Segera mandi dan berganti pakaian sebelum kontak dengan anggota keluarga di rumah.

8) Jika diperlukan, bersihkan handphone, kacamata, tas, dan barang lainnya dengan cairan disinfektan.

9) Saat tiba di rumah, segera mandi dan berganti pakaian sebelum kontak dengan anggota keluarga di rumah. Bersihkan handphone, kacamata, tas, dan barang lainnya dengan cairan disinfektan.

\subsection{Manajemen Strategis}

Manajemen strategis merupakan satu set rangkaian aktivitas untuk mengambil sebuah keputusan yang bersifat mendasar dan disertai penerapan aplikasinya yang dibuat oleh pimpinan suatu perusahaan dan dilaksanakan oleh semua pihak-pihak yang terlibat dalam perusahaan tersebut dalam mencapai tujuan yang diharapkan. (Yunus, 2016, hlm 6)

\subsection{Strategi Pengembangan Bisnis}

Raharja dalam (Herawaty \& Raharja, 2018, hlm 395) mengemukakan bahwa "A strategy is essential for all companies to be able to compete with similar companies based on internal performance or external company" [Strategi sangat penting bagi semua perusahaan untuk dapat bersaing dengan perusahaan yang sejenis berdasarkan kinerja internal maupun eksternal perusahaan].

Menurut Hunger dan Wheelen dalam (Brahmanto et al., 2017, hlm 591)
"Manajemen strategis mengamati lingkungan eksternal untuk melihat kesempatan dan ancaman, serta mengamati lingkungan internal melihat kekuatan dan kelemahan. Faktor-faktor lingkungan itu disebut dengan SWOT yaitu : Strengths, Weaknesses, Opportunities, and Threats.

Pengembangan bisnis merupakan penciptaan sebuah nilai jangka panjang suatu perusahaan maupun organisasi dari pasar, konsumen dan juga relasi. Pengembangan bisnis juga dapat diartikan sebagai hal-hal yang berkaitan dengan bagaimana interaksi faktor-faktor yang berkombinasi untuk menciptakan peluang tumbuh. (Anjani, 2018, hlm 10)

\section{Kesimpulannya}

Strategi

Pengembangan Bisnis adalah suatu proses yang terarah dan direncanakan dengan mengamati lingkungan eksternal dan internal suatu perusahaan meliputi faktor-faktor lingkungan yang disebut sebagai SWOT (Strenghts, Weaknesses, Opportunities, and Threats). Bertujuan agar perusahaan dapat bersaing dan dapat menciptakan peluang untuk tumbuh di masa yang akan datang.

\subsection{Analisis SWOT}

Utami dalam (Kurniawan et al. 2020, hlm 72) memaparkan bahwa "SWOT analysis is one way to find out internal and external conditions regarding the business being carried out" [Analisis SWOT merupakan salah satu cara untuk mengetahui kondisi internal dan eksternal mengenai bisnis yang dijalankan].

Unsur-unsur analisis SWOT diantaranya adalah sebagi berikut:

\section{a. Faktor Eksternal}

Faktor ini mempengaruhi terbentuknya peluang juga ancaman (opportunities and threats). Dimana faktor ini berkaitan dengan kondisi-kondisi yang terjadi diluar suatu perusahaan. Faktor ini meliputi lingkungan bisnis makro, ekonomi, lingkungan industri, kependudukan, hukum, sosial budaya, 
teknologi, lingkungan bisnis makro.

\section{b. Faktor internal}

Faktor ini mempengaruhi adanya strenghts and weaknesses. Dimana faktor ini berkaitan dengan kondisi yang terjadi di dalam perusahaan yang bersangkutan. Dimana hal tersebut mempengaruhi terbentuknya pembuatan keputusan atau decision making suatu perusahaan. Faktor ini mencakup beberapa aspek diantaranya: pemasaran, operasi, sumber daya manusia (SDM), keuangan, penelitian dan pengembangannya, sistem informasi manajemen dan juga budaya perusahaan (corporate culture). (Ranita \& Hanum, 2016, hlm 17)

\subsection{Model Analisis SWOT}

Dalam penggunaan Analisis SWOT, kedua faktor dibandingkan yaitu faktor eksternal berupa peluang dan ancaman, serta faktor internal berupa kekuatan dan juga kelemahan terlebih dahulu. Untuk faktor eksternal menggunakan matrik yang sering disebut matrik EFE (External Factor Evaluation), dan untuk faktor internal, matrik yang digunakan ialah matrik IFE (Internal Factor Evaluation).

\section{Matriks EFE}

Menurut Sukma dan Wahdjuadi (2017, hlm 207) EFE adalah sebuah kesimpulan yang didapat dari analisis berbagai faktor eksternal yang mempengaruhi berjalannya suatu perusahaan. Sedangkan matriks EFE biasanya digunakan untuk menentukan semua faktor eksternal yang akan mempengaruhi perusahaan meliputi peluang dan juga ancaman dari luar perusahaan atau lingkungan bisnis. Faktor-faktor tersebut akan dibobot dan juga diberikan rating untuk dihitung skornya.

\section{Matriks IFE}

IFE merupakan sebuah kesimpulan yang didapat dari analisis berbagi faktor internal yang mempengaruhi berjalannya suatu perusahaan. Menurut Sukma dan Wahdjuadi (2017, hlm 206-207) matriks IFE merupakan matriks yang digunkan untuk menentukan segala faktor internal perusahaan yang menjadi daya saing dari perusahaan, meliputi kekuatan dan juga kelemahan perusahaan. Sama hal nya seperti matriks EFE, pada matriks IFE faktor-faktor kekuatan dan kelemahan yang menjadi faktor internal perusahaan juga akan dibobot dan diberikan rating untuk dihitung berapa skornya.

\section{Matriks IE}

Menurut Syamruddin (2020, hlm 120) matriks IE merupakan matriks yang menentukan dimana posisi strategi bisnis dalam sembilan sel (kuadran). Input dari matrik IE merupakan output dari matriks IFE dan EFE. Output dari matriks IE merupakan alternatif strategi menurut posisi strategi perusahaan setelah dibuat sebagi matriks di mana terdapat tiga area alternatif.

Umar dalam (Rahmawan 2018, hlm 24-25) memaparkan bahwa "matriks internal dan eksternal terdiri atas dua dimensi, nilai total IFE berada pada sumbu Y sedangkan nilai total EFE berada pada sumbu $X$. sumbu $X$ memiliki tiga rating skor yaitu, 1,0 - 1,99 berarti posisi internal lemah, skor 2,0 - 2,99 merupakan rata-rata, dan 3,0 - 4,0 menyatakan bahwa posisi kuat dan hal tersebut ditetapkan dari sebelah kanan ke kiri. Hal yang sama juga berlaku terhadap sumbu Y. skor 1,0 - 1,99 berarti posisi eksternal lemah, skor 2,0 - 2,99 merupakan rata-rata, dan 3,0 - 4,0 menyatakan bahwa posisi kuat dan hal tersebut ditetapkan dari bawah ke atas."

\section{Matriks SWOT}

Umar dalam Rahmawan (2018, hlm 24) menjelaskan bahwa dalam matriks SWOT terdapat 4 set kemungkinan alternatif strategi yaitu:

1. Strategi SO (Strenght-Opportunities)

Strategi ini dibuat berdasarkan jalan pikiran suatu perusahaan, dengan cara memanfaatkan seluruh kekuatan untuk menggunakan peluang yang ada sebaik-baiknya. 
2. Strategi ST (Strength-Threats)

Merupakan strategi di mana kekuatan suatu perusahaan digunakan untuk mengatasi ancaman dari luar.

3. Strategi WO (Weakness-Opportunities) Strategi ini digunakan untuk memanfaatkan suatu peluang yang ada dengan cara meminimalkan kelemahan yang dimiliki oleh suatu perusahaan.

\section{Strategi WT (Weakness-Threats)}

Strategi ini bersifat devensif dan dengan strategi ini diharapkan dapat meminimalkan kelemahan yang dimiliki serta menghindari dari ancaman yang akan ada.

\section{Matriks QSPM}

Matriks QSPM (Quantitative Strategic Planning Matriks) adalah suatu teknik analisis dalam sebuah literatur yang di rancang untuk menjadi daya tarik relatif dari tindakan alternatif yang dijalankan. (Sukma \& Wahdjuadi, 2017, hlm 205)

\section{Material dan Metode}

\subsection{Metode Penelitian}

Penelitian ini menggunakan mixed methods atau metode campuran antara kualitatif dan kuantitatif dengan tipe embedded design. Kajamaa et al. (2020, hlm 2) mengemukakan bahwa "Mixed-methods research, or multi-strategy designs, can be defined as the colection, analysis and integration of both qualitative and quantitative data in single study..." [Metode penelitian campuran, atau desain multi-strategi, dapat dideinisikan sebagai pengumpulan, analisis dan integrasi data kualitatif dan kuantitatif dalam satu studi...]. "Mixed methods tipe embedded design ini malah cenderung memberikan kebebasan pada peneliti untuk memilih salah satu metode untuk diprioritaskan. Creswell (2012) menyebutkan bahwa kekuatan dari embedded design ini adalah terletak pada pemanfaatan kombinasi kelebihan dari kedua metode penelitian." (Vebrianto et al., 2020, hlm 65)

Gambar 3 Mixed methods tipe embedded design Creswell

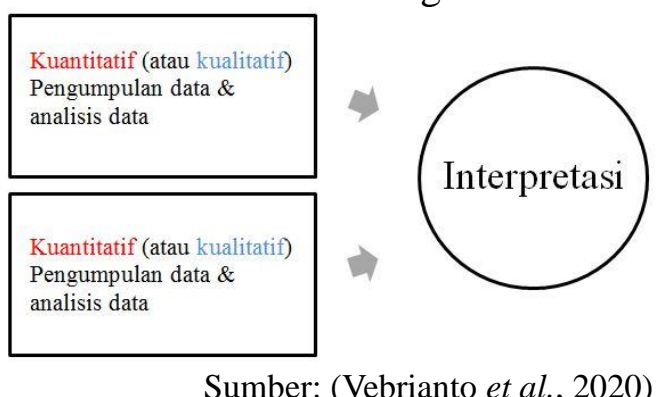

\subsection{Objek dan Subjek Penelitian}

Objek dari penelitian ini adalah Katering Al-Raham yang merupakan salah satu usaha jasaboga yang berada di Kabupaten Bandung. Katering Al-Raham termasuk ke dalam katering golongan A2 yang melayani kebutuhan masyarakat umum dengan pengolahan menggunakan dapur rumah tangga dan mempekerjakan tenaga kerja. Sedangkan subjek dari penelitian ini adalah pemilik atau owner dari Katering Al-Raham, karyawan katering Al-Raham, dan juga konsumen atau pelanggan katering Al-Raham.

\subsection{Sumber Data}

Menurut cara memperolehnya data dibagi menjadi dua yaitu:

a. Data primer menurut Purhantara dalam Rahmawan (2018, hlm 44) merupakan data yang secara langsung diperoleh dari subjek penelitian, penulis mendapatkan data tersebut secara langsung dengan instrumen yang sebelumnya telah ditetapkan. Dalam penelitian ini, sumber data primer diperoleh penulis melalui wawancara dengan pemilik serta observasi secara langsung ke Katering Al-Raham Kabupaten Bandung.

b. Data sekunder adalah data yang dibuat bukan oleh pengolahnya, dengan kata 
lain data tersebut diterbitkan oleh organisasi diluar perusahaan tempat penelitian (Martadi et al., 2021, hlm 43). Sumber data sekunder diperoleh penulis melalui website resmi Badan Pusat Statistik Kabupaten Bandung.

\subsection{Populasi dan Sampel}

\subsection{Teknik Pengumpulan Data}

Dalam penelitian dilakukan beberapa teknik pengumpulan data sebagai berikut:

a. Wawancara

Wawancara merupakan teknik pengumpulan data yang dilakukan dengan cara mengajukan pertanyaan - pertanyaan kepada responden yang menjadi narasumber (Abbas et al., 2020, hlm 123). Wawancara yang penulis lakukan merupakan wawancara terstruktur dan juga terbuka di mana pertanyaan-pertanyaan yang di ajukan oleh penulis, sudah dicatat penulis terlebih dahulu dan narasumber mengetahui maksud dan tujuan dari wawancara tersebut. Dalam penelitian ini yang menjadi narasumber untuk di wawancarai adalah pemilik (owner) dari Katering Al-Raham, dengan tujuan untuk mendapatkan data mengenai faktor-faktor internal perusahaan seperti data keuangan, struktur organisasi, visi dan misi perusahaan, produk, SDM, pemasaran, higiene dan sanitasi, serta protokol kesehatan yang dilakukan di masa pandemi COVID-19.

b. Observasi

Purhantara dalam (Anjani, 2018, hlm 47) mengemukakan bahwa "Metode observasi dapat menghasilkan data yang lebih rinci mengenai perilaku (subjek), benda, atau kejadian (objek) daripada metode wawancara". Dalam penelitian ini penulis melakukan observasi langsung ke tempat penelitian dengan cara mengunjungi serta mengamati tempat penelitian tersebut secara langsung. Penulis mengobservasi tempat produksi untuk memperoleh data tingkat kebersihan yang diterapkan di Katering Al-Raham, serta kualitas produk seperti rasa, aroma, dan penampilan dari produk yang dihasilkan.
c. Dokumentasi
Dokumentasi merupakan salah satu hal yang sangat penting dalam sebuah penelitian. Dokumentasi sendiri dapat diartikan sebagai sebuah teknik pengumpuan data dengan cara mencri tahu mengenai variabel berupa surat-surat, buku, transkrip dan yang lainnya. Singkatnya, dalam teknik pengambilan data dokumentasi lebih mengamati pada benda mati (Anjani, 2018, hlm 48). Dalam penelitian ini, instrumen dokumentasi secara internal yang digunakan adalah pembukuan keuangan katering Al-Raham untuk mengetahui omset dari katering tersebut, sedangkan untuk dokumentasi secara eksternal menggunakan katalog Badan Pusat Statistik Kabupaten Bandung, surat kabar online yaitu liputan6.com dan jabar.tribunne. Selain itu, penulis juga mendokumentasikan dalam bentuk foto-foto Katering Al-Raham.

d. Kuesioner $\quad$ adalah teknik mengumpulkan data-data yang dilakukan dengan cara komunikasi dengan sumber data (Risanty \& Sopiyan, 2017, hlm 3). Kuesioner mempunyai peran yang juga penting dalam pengumpulan data yang berkaitan dengan penentuan sampel untuk mendapatkan informasi semaksimal mungkin. Dalam penelitian ini penulis menyebarkan kuesioner berupa lembar kuesioner (hardfile) untuk memperoleh data kepuasan kerja karyawan yang diperoleh dari karyawan di Katering Al-Raham dan juga kuesioner online menggunakan google form untuk memperoleh data kepuasan konsumen yang disebarkan kepada konsumen Katering Al-Raham.

\section{Hasil dan Pembahasan}

\subsection{Matriks IFAS}

Hasil dari penelitian ini berdasarkan matriks IFAS terdapat 10 kekuatan dan 5 kelemahan yang dimiliki Katering Al-Raham. Dapat dilihat pada tabel 1 di bawah ini: 
Tabel 1 Hasil Penelitian Lingkungan Internal Katering Al-Raham

\begin{tabular}{|c|c|c|c|}
\hline Faktor Strategis Internal & Bobot & Rating & Nilai \\
\hline \multicolumn{4}{|l|}{ Kekuatan } \\
\hline 1. Kinerja dan dukungan dari atasan & 0,07 & 3 & 0,21 \\
\hline 2. Penampilan, rasa, dan porsi dari makanan & 0,10 & 4 & 0,4 \\
\hline $\begin{array}{l}\text { 3. Kulitas pelayanan yang diberikan oleh } \\
\text { karyawan }\end{array}$ & 0,09 & 4 & 0,36 \\
\hline 4. Kebersihan alat makan dan katering & 0,07 & 3 & 0,21 \\
\hline 5. Lingkungan kerja karyawan & 0,06 & 2 & 0,12 \\
\hline 6. Kejelasan SOP & 0,05 & 2 & 0,1 \\
\hline 7. Standardisasi pengadaan bahan baku & 0,10 & 4 & 0,4 \\
\hline 8. Kemudahan akses lokasi & 0,07 & 3 & 0,21 \\
\hline 9. Kesesuaian gaji & 0,06 & 2 & 0,12 \\
\hline 10. Harga yang sesuai dan bersaing & 0,10 & 4 & 0,4 \\
\hline \multicolumn{4}{|l|}{ Kelemahan } \\
\hline 1. Struktur organisasi & 0,02 & 1 & 0,02 \\
\hline 2. Pilihan menu dan dekorasi & 0,06 & 2 & 0,12 \\
\hline 3. Standardisasi perekrutan karyawan & 0,05 & 2 & 0,1 \\
\hline 4. Promosi atau pemasaran & 0,02 & 1 & 0,02 \\
\hline 5. Target penjualan & 0,02 & 1 & 0,02 \\
\hline 6. Protokol kesehatan & 0,05 & 2 & 0,1 \\
\hline TOTAL & 1,00 & & 2,91 \\
\hline
\end{tabular}

\subsection{Matriks EFAS}

ancaman bagi Katering Al-Raham. Dapat

Hasil penelitian berdasarkan matriks

EFAS yaitu terdapat 5 peluang dan juga 2

Tabel 2 Hasil Penelitian Lingkungan Eksternal Katering Al-Raham

\begin{tabular}{|c|c|c|c|}
\hline Faktor Strategis Eksternal & Bobot & Rating & Nilai \\
\hline \multicolumn{4}{|l|}{ Peluang } \\
\hline $\begin{array}{l}\text { 1. Target pasar yang luas dari kalangan menengah } \\
\text { ke bawah hingga menengah }\end{array}$ & 0,14 & 2 & 0,28 \\
\hline $\begin{array}{l}\text { 2. Kondisi sosial masyarakat terhadap } \\
\text { tren pernikahan }\end{array}$ & 0,14 & 2 & 0,28 \\
\hline $\begin{array}{l}\text { 3. Lokasi yang dekat dengan instansi dan sektor } \\
\text { pendidikan }\end{array}$ & 0,10 & 2 & 0,2 \\
\hline 4. Media promosi yang bisa dimanfaatkan & 0,17 & 2 & 0,34 \\
\hline $\begin{array}{l}\text { 5. Potensi bisnis katering yang menjanjikan di } \\
\text { Kabupaten Bandung }\end{array}$ & 0,17 & 2 & 0,34 \\
\hline \multicolumn{4}{|l|}{ Ancaman } \\
\hline $\begin{array}{l}\text { 1. Ketatnya persaingan industri katering di } \\
\text { Kabupaten Bandung }\end{array}$ & 0,14 & 2 & 0,28 \\
\hline 2. Adanya inflasi yang berpengaruh terhadap & 0,14 & 2 & 0,28 \\
\hline
\end{tabular}




\begin{tabular}{|l|l|l|c|}
\hline harga bahan baku & & & \\
\hline TOTAL & 1,00 & & 2,01 \\
\hline
\end{tabular}

\subsection{Matriks IE}

Tahap selanjutnya setelah menilai apa yang menjadi faktor internal dan eksternal adalah menentukan matriks IE untuk menentukan posisi sel dari Katering Al-Raham dengan titik koordinat $\mathrm{X}$ total nilai IFE dan Y total nilai EFE $(2,91 ; 2,01)$. Berikut ini adalah matriksnya:

Gambar 1 Matriks IE Katering Al-Raham

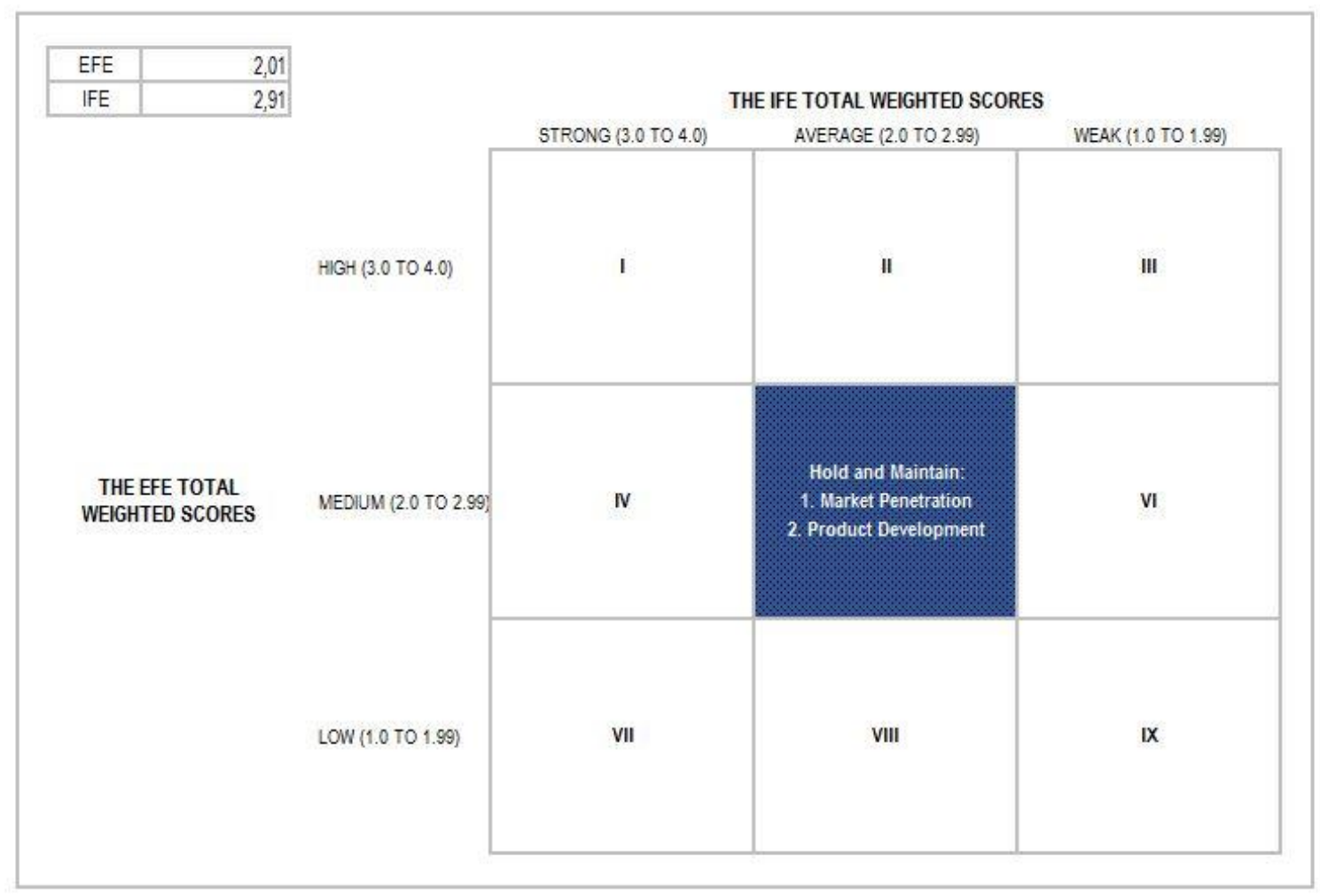

Pada gambar di atas terlihat bahwa posisi Katering Al-Raham berada dalam kuadran V. Menurut Umar dalam (Rahmawan, 2018) apabila hasil kuadran berada pada sel ke-5 maka strategi yang sebaiknya digunakan adalah strategi Hold and Maintain (jaga dan pertahankan). Katering Al-Raham perlu menjaga dan mempertahankan kualitas pelayanan dan kualitas produk yang mereka miliki. Strategi pengembangan yang umumnya dilakukan adalah strategi Market Penetration serta Product Development. Menurut Robinson dkk, dalam (Kurniawan et al., 2020, hlm 72) strategi pengembangan produk merupakan suatu strategi yang memiliki konsep atau produk yang baru untuk ditawarkan kepada konsumen strategi ini bertujuan untuk mengembangkan produk agar konsumen memiliki pengalaman yang lebih baik dan juga pengembanngan produk ini penting untuk melakukan refreshment bagi konsumen yang sudah ada. Sedangkan strategi penetrasi pasar merupakan strategi yang digunakan untuk meningkatkan basis pelanggan dan juga pembelian oleh konsumen.

\subsection{Kuadran SWOT}

Tahap berikutnya setelah mengetahui posisi sel Katering Al-Raham adalah menentukan posisi kuadran SWOT bagi katering ini. Berikut merupakan hasil kuadran SWOT dari Katering Al-Raham: 
Gambar 2 Hasil Kuadran SWOT Katering Al-Raham

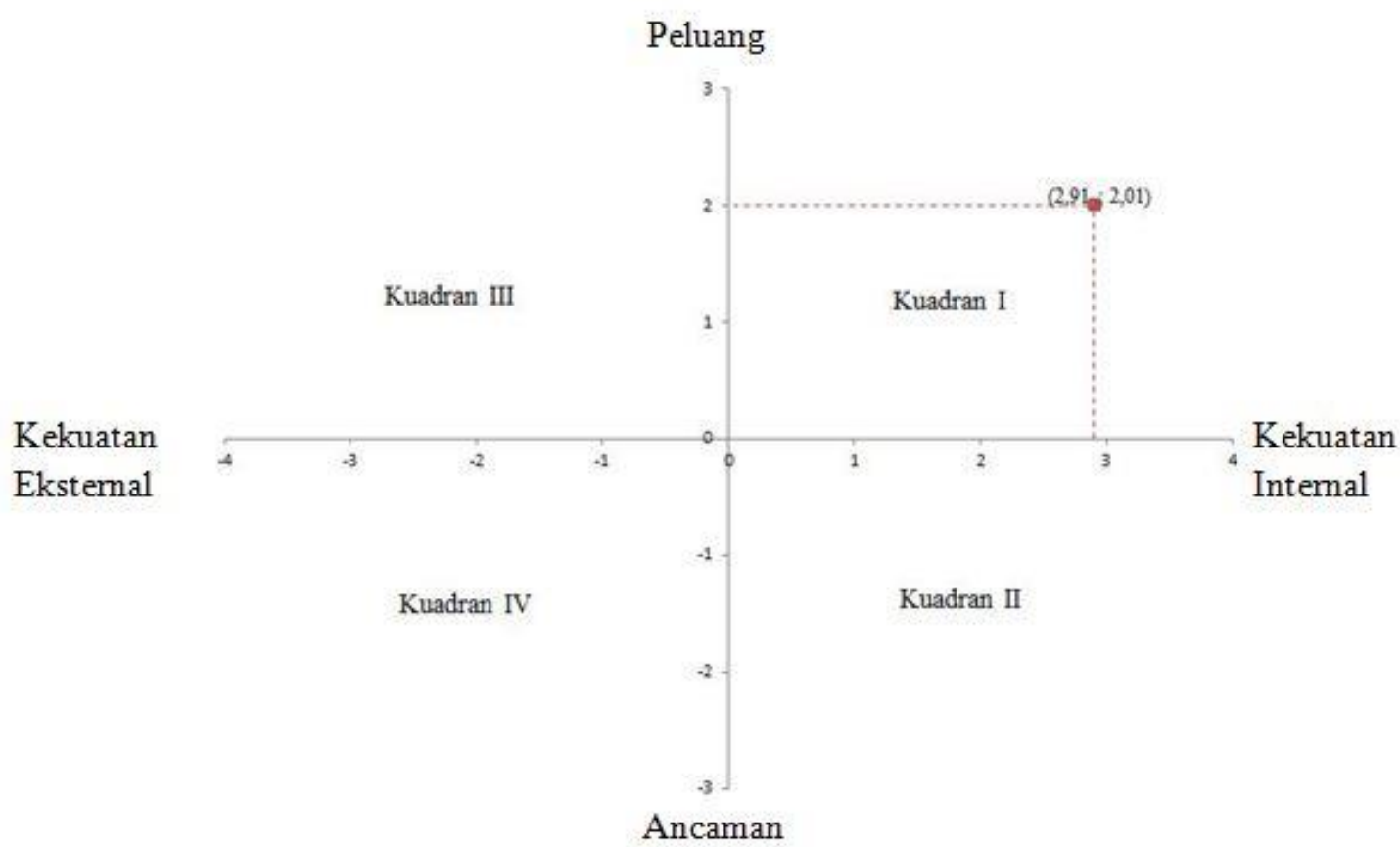

Berdasarkan posisi pada diagram di atas, posisi Katering Al-Raham berada di kuadran 1 yang berarti katering memiliki peluang dan juga kekuatan untuk mengembangkan bisnisnya. Strategi yang mendukung kondisi katering ini adalah strategi bagi pertumbuhan agresif (Rangkuti, 2013, hlm 199). Strategi pertumbuhan agresif yang harus diterapkan oleh Katering Al-Raham adalah meningkatkan kapasitas produksi, meningkatkan promosi untuk memperoleh pasar yang lebih luas, membenahi struktur organisasi, meningkatkan kreatifitas poduk, mematuhi protokol kesehatan saat pandemi, melakukan kerjasama dengan vendor atau mitra usaha.

\subsection{Matriks SWOT}

Setelah dilakukan analisis faktor internal dan eksternal menggunakann matriks SWOT, diperoleh strategi alternatif sebagai berikut:

a. Startegi SO (Strength-Opportunity)

1. Meningkatkan penetrasi pada produk dengan harga yang tetap terjangkau dan kompetitif. Mempertahankan kualitas kebersihan dan standardisasi pengadaan bahan baku. Dalam strategi ini salah satu cara untuk mengimplementasikanya adalah mengadakan acara dengan mengajak vendor-vendor atau perusahaan lain. Tujuannya agar konsumen dapat menilai dan lebih mengetahui kualitas produk dari Katering Al-Raham.

2. Mempertahankan kualitas pelayanan agar tidak kehilangan konsumen tetap. Melakukan promosi di berbagai media sosial. Perusahaan dapat memanfaatkan keadaan pandemi saat ini yang mayoritas orang lebih banyak berdiam di rumah dengan melakukan promosi di media sosial yang banyak dignakan oleh masyarakat luas seperti instagram, facebook, tiktok, dsb. Selain itu katering ini juga dapat bermitra usaha dengan perusahaan layanan pesan antar makanan seperti gojek, grab, dan shopee.

b. Strategi WO (Weakness-Opportunity)

1. Membenahi struktur organisasi dan 
membuat pilihan menu untuk meraih lebih banyak pasar. Dalam hal ini katering dapat merekrut pegawai dibagian pemasaran agar lebih maksimal promosi yang dijalankan.

2. Melakukan promosi berdasarkan segmen pasar dengan mempertimbangkan kondisi pandemi saat ini. Serta menentukan target penjualan agar menjadi acuan untuk berkembang. Promosi disesuaikan dengan segmen pasar yang dimiliki yaitu menengah ke bawah sampai menengah dengan mempertimbangkan kondisi pandemi Covid-19. Dan tentukan target penjualannya.

c. Strategi ST (Strength-Threat)

1. Memaksimalkan potensi keunggulan produk dan pelayanan yang kompetitif agar dapat unggul ditengah ketatnya persaingan dan naiknya bahan baku. Kualitas pelayanan dan produk dapat menjadi nilai tambah bagi Katering Al-Raham, oleh karena itu kualitasnya harus tetap dipertahankan.

d. Strategi WT (Weakness-Threat)

1. Mengobservasi dan melakukan standardisasi pada semua lini perusahaan dengan mematuhi protokol kesehatan seperti melakukan standardsasi perekrutan karyawan, operasional, protokol kesehatan dan semua aspek perusahaan bagi karyawan.

\subsection{Matriks SWOT}

Berdasarkan data hasil perhitungan matriks QSPM telah ditentukan strategi prioritas yang dapat digunakan oleh Katering Al-Raham. Berikut merupakan urutan strategi prioritasnya.

1. Mempertahankan kualitas pelayanan agar tidak kehilangan konsumen tetap. Melakukan promosi di berbagai media sosial.

Perusahaan

dapat memanfaatkan keadaan pandemi saat ini yang mayoritas orang lebih banyak berdiam di rumah dengan melakukan promosi di media sosial yang banyak digunakan oleh masyarakat luas seperti instagram, facebook, tiktok, dsb. Selain itu katering ini juga dapat bermitra usaha dengan perusahaan layanan pesan antar makanan seperti gojek, grab, dan shopee.

2. Melakukan promosi berdasarkan segmen pasar dengan mempertimbangkan kondisi pandemi saat ini. Serta menentukan target penjualan agar menjadi acuan untuk berkembang. Promosi disesuaikan dengan segmen pasar yang dimiliki yaitu menengah ke bawah sampai menengah dengan mempertimbangkan kondisi pandemi Covid-19.

3. Membenahi struktur organisasi dan membuat pilihan menu untuk meraih lebih banyak pasar. Dalam hal ini katering dapat merekrut pegawai dibagian pemasaran agar lebih maksimal promosi yang dijalankan.

4. Memaksimalkan potensi keunggulan produk dan pelayanan yang kompetitif agar dapat unggul ditengah ketatnya persaingan dan naiknya bahan baku. Kualitas pelayanan dan produk dapat menjadi nilai tambah bagi Katering Al-Raham, oleh karena itu kualitasnya harus tetap dipertahankan.

5. Meningkatkan penetrasi pada produk dengan harga yang tetap terjangkau dan kompetitif. Mempertahankan kualitas kebersihan dan standardisasi pengadaan bahan baku. Dalam strategi ini salah satu cara untuk mengimplementasikanya adalah mengadakan acara dengan mengajak vendor-vendor atau perusahaan lain. Tujuannya agar konsumen dapat menilai dan lebih mengetahui kualitas produk dari Katering Al-Raham.

6. Mengobservasi dan melakukan standardisasi pada semua lini 
perusahaan dengan mempertimbangkan keadaan pandemi agar dapat bertahan ditengah ketatnya persaingan. Standardisasi mencakup perekrutan karyawan, operasional, protokol kesehatan saat pandemi dan semua aspek yang mencakup informasi perusahaan bagi karyawan.

\section{Kesimpulan}

Berdasarkan hasil penelitian yang sudah dilakukan, dapat ditarik kesimpulan bahwa Katering Al-Raham memiliki beberapa faktor internal yang menjadi kekuatan untuk bersaing dengan katering lainnya diantaranya adalah kualitas dari produk yang dihasilkan (rasa, kombinasi warna, dan porsi), kebersihan produk dan juga katering, kualitas yang dimiliki karyawannya berdasarkan pelayanan yang diberikan, lingkungan kerja karyawan, peran dan juga dukungan dari atasan, standardisasi pengadaan bahan baku, kejelasan SOP, kemudahan akses lokasi, kemudahan transaksi serta harga yang sesuai dan kompetitif.

Peneliti juga mendapatkan beberapa faktor internal yang menjadi kelemahan bagi katering ini diantaranya adalah struktur organisasi, protokol kesehatan yang belum maksimal, promosi yang belum optimal, menu yang ditawarkan belum jelas, standardisasi suhu makanan yang disajikan, standardisasi perekrutan karyawan, target penjualan yang belum ditentukan, serta pembukuan keuangan yang masih manual. Selain faktor internal adapun faktor-faktor eksternal yang menjadi peluang katering ini untuk berkembang diantaranya industri katering yang prospektif dan berpotensi tinggi untuk tidak mati serta adanya peluang di masa pandemi dengan membenahi pemasaran dan kreatifitas produk. Selain itu, target pasar katering ini yang cukup luas dan juga banyaknya media sosial yang dapat digunakan untuk pemasaran dapat menjadi keuntungan bagi katering ini. Adapun faktor eksternal berupa ancaman diantaranya faktor inflasi dalam kenaikan jumlah pengeluaran yang juga berpengaruh terhadap harga bahan baku, ketatnya persaingan katering di kabupaten bandung juga dapat menjadi salah satu ancaman bagi katering ini.

Faktor eksternal dan juga internal yang sudah disebutkan diatas menjadi bahan pertimbangan penulis untuk merumuskan beberapa strategi yang dapat diterapkan dalam pengembangan bisnis Katering Al-Raham. Berdasarkan hasil dari matriks IE diatas posisi katering ini berada pada sel $\mathrm{V}$ dengan titik koordinat $(2,95 ; 2,05)$ dan strategi yang efektif dilakukan adalah penetrasi pasar serta pengembangan produk. Alternatif strategi yang dapat katering Al-Raham terapkan adalah pemanfaatan teknologi untuk melakukan promosi di media sosial seperti instagram, facebook, tiktok, dsb. Selain itu katering itu jug dapat melakukan refreshment pada produk dengan cara melakukan inovasi menu paket yang ditawarkan.

\section{Referensi}

Abbas M, Sari N, Nasra N, Elihami, E. 2020. Peranan Lapangan Perlembagaan di Lembaga Kursus Dan Pelatihan Dian Ayu di Kabupaten Sidenreng Rappang. Jurnal Edukasi Nonformal, 1(1): 122-138. e-ISSN: 2715-2634.

Anjani, Astrid Dwi. 2018. Strategi Pengembangan Bisnis Rumah Makan Ganbatte Suki, Bbq \& Steak Bandung. Thesis, Fakultas Pendidikan Ilmu Pengetahuan Sosial, Universitas Pendidikan Indonesia.

Anjani A, Ningsih C, Fajri I. 2018. Strategi Pengembangan Bisnis Rumah Makan Ganbatte Suki, Bbq \& Steak Bandung. Gastronomy Tourism Journal, 4(2): 8-21. e-ISSN: 2716-3970.

[BPS] Badan Pusat Statistik Kabupaten Bandung. 2019. Bandung Regency in Figures [internet]. [diacu 28 Maret 2021] tersedia dari: https://bandung kab.bps.go.id.

Brahmanto E, Hermawan H, Hamzah F. 2017. Strategi Pengembangan 
Kampung Batu Malakasari Sebagai Daya Tarik Wisata Minat Khusus. Jurnal Media Wisata, 15(2): 588-600. doi: https://doi.org/10.36276/mws.v15 i2.295.

Ferreira, Jessica; Sousa, Bruno. 2020. Experiental mareting as laverage for growth of creative tourism: A co-creative proces. Smart Innovation, Systems and Technologies, 171(1): 567-577. doi: https://doi.org/10.1007/978-981-15-20 24-2_49.

Gardjito M, Hendrasty H, Dewi A. 2016. Industri Jasa Boga. Yogyakarta: Gajah Mada University Press.

Herawaty, Tetty; Raharja, Sam'un Jaja. 2018. Creative Industry Development Strategy in Bandung, Indonesia. Review of Integrative Business and Economics Research, 7(2): 394-403. eISSN: 2304-1013.

Jayanti, Nur Dwi. 2016. Kualitas Pelayanan (Reliability, Responsiveness, Assurance, Emphaty, Tangibles ) di Legend Premium Coffee Yogyakarta. Thesis, Fakultas Teknik, Universitas Negeri Yogyakarta.

Kajamaa A, Mattick K, Croix A. 2020. How to do Mixed Methods Research. The Clinical Teacher, 17(3): 267-271. doi: https://doi.org/10.1111/tct.13145.

Kurniawan D, Iswahyudin M, Suciati T. 2020. SWOT Analysis and Ansoff Matrix in Creative Food Industry Business Development: A Study on Creative Food Business "Komala". Abasyn Journal of Social Sciences, 3(2): 69-76. doi: https://doi.org/10.37275/OAIJSS.v3i2. 29.

Martadi, Utami S, Subekhi. 2021. Evaluasi Jaringan Sekunder Daerah Irigasi (D.I) Kenconorejo Kecamatan Tulis Tulis Kabupaten Batang Jawa Tengah. Journal Reviews in Civil Engineering, 5(1): 40-47. e-ISSN: 2614-3119.

[MENKES] Menteri Kesehatan. 2011. Peraturan Menteri Kesehatan Nomor
1096 tahun 2011 tentang Higiene Sanitasi Jasaboga [internet]. [diacu 24 Maret 2021] tersedia dari: http://pelayanan.jakarta.go.id/downloa d/regulasi/permen-kesehatan-nomor-1 096-menkes-per-vi-2011-tentang-higie ne-sanitasi-jasaboga.pdf.

[MENKES] Menteri Kesehatan. 2020. Protokol Kesehatan bagi Masyarakat di Tempat dan Fasilitas Umum dalam Rangka Pencegahan dan Pengendalian Corona Virus Disease 2019 (Covid-19) [internet]. [diacu 11 Juli 2021] tersedia dari:

https://covid19.kemkes.go.id/protokolcovid-19/protokol-kesehatan-bagi-mas yarakat-di-tempat-dan-fasilitas-umumdalam-rangka-pencegahan-covid-19.

Primanda. 2018. Bandung Kembali Dinobatkan sebagai Kota Pariwisata Terbaik [internet]. [diacu 24 Maret 2021] tersedia dari: https://humas.bandung.go.id/berita/ban dung-kembali-dinobatkan-sebagai-kota -pariwisata.

Rahmawan, Deden Luthfi. 2018. Strategi Pengembangan Bisnis I Burahay Catering Bandung. Thesis, Fakultas Pendidikan Ilmu Pengetahuan Sosial, Universitas Pendidikan Indonesia.

Ranita S; Hanum Z. 2016. Revenue Cost dan Analisis Swot Dalam Pengembangan Usaha. Jurnal Bisnis Administrasi, 5(2): 14-19. e-ISSN: 2597-4394.

Rangkuti, Freddy. 2013. SWOT BALANCED SCORECARD. Jakarta: PT Gramedia Pustaka Utama.

Risanty R; Sopiyan A. 2017. Mengajar Menggunakan Bot Telegram Pada Fakultas Teknik Universitas Muhammadiyah Jakarta ( Ft-Umj ) Dengan Metode Polling. Seminar Nasional Sains dan Teknologi, 1(1): 1-9. e-ISSN: $2460-8416$.

Sukma O; Wahdjuadi D. 2017. Formulasi Strategi Bisnis Pada Konveksi Inglorious Industries Di Kota Bandung Tahun 2017-2021. Ekonomi Bisnis 
Telkom, 4(1): 203-211. e-ISSN: 2355-9357.

Suprihatin, Wiwik. 2020. Analisis Perilaku Konsumen Wisatawan Era Pandemi Covid-19 ( Studi Kasus Pariwisata di Nusa Tenggara Barat ) Analysis of Tourist Consumer Behavior in the Covid-19 Pandemic Era ( Case Study of Tourism in West Nusa Tenggara ). Jurnal Bestari, 1(1): 56-66. eISSN: 2745-7001.

Syamruddin. 2020. Analisis Kelayakan Usaha Baby Buncis Kenya Kelompok Tani " Baby French Farmer Group " Dari Aspek IFAS , EFAS, dan IE. Jurnal Madani, 3(1): 118-131. doi: https://doi.org/10.33753/madani.v3i1.1 00.

Vebrianto R, Thahir M, Putriani Z,
Mahartika I, Ilhami A.2020. Mixed Methods Research: Trends and Issues in Research Methodology. Journal of Education and Learning, 1(1): 63-73. e-ISSN: 2723-0384.

Yunus, Eddy. 2016. Manajemen Strategis. Yogyakarta: CV ANDI OFFSET. 